\title{
New induction agents
}

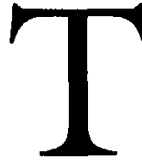

HERE are several new compounds and new formulations being clinically evaluated as intravenous anaesthetics. The aim is to find agents with properties near to the ideal (Table). The anaesthetist also has at his disposal new technologies for the delivery of hypnotic agents.

TABLE Properties of the ideal intravenous anaesthetic agent.

\begin{tabular}{l}
\hline Physical properties \\
Water soluble \\
stable in solution \\
long shelf life \\
no pain on intravenous injection \\
non-irritant on subcutaneous injection \\
pain on arterial injection \\
no sequelae from arterial injection of small doses \\
low incidence of venous thrombosis \\
small volume of an isotonic solution required for induction \\
Pharmacological properties \\
Minimal cardiorespiratory depression \\
does not cause histamine release; or predispose to \\
hypersensitivity reactions \\
induction in one arm-brain circulation time \\
metabolism to pharmacologically inactive metabolites \\
no myoneural blockade
\end{tabular}

\section{New formulations}

Methohexitone, etomidate, propanidid and propofol

Lipid emulsions are normally used to formulate drugs that are water-insoluble; however they may also be used as carriers of hydrophilic compounds that cause significant side-effects such as pain on injection (methohexitone) or pain on injection and venous sequelae (etomidate). In a volunteer study, Westrin et al. have compared aqueous methohexitone with an emulsion formulation of the barbiturate. ${ }^{1}$ The incidence of spontaneously reported "pain on injection" was reduced from $83 \%$ to zero, and visual analogue pain scores from $38 \mathrm{~mm}$ to $5 \mathrm{~mm}$. In a further evaluation in 42 unpremedicated patients undergoing a variety of surgical procedures, the $\mathrm{ED}_{50}$ (hypnotic dose causing loss of consciousness in $50 \%$ subjects) for the emulsion formulation was $1.2 \pm 0.1 \mathrm{mg} \cdot \mathrm{kg}^{-1}$ and $1.1 \pm 0.1 \mathrm{mg} \cdot \mathrm{kg}^{-1}$ for aqueous methohexitone - show- ing that this change in formulation did not appear to affect potency.

Studies with a lipid emulsion formulation of etomidate have shown no change in the pharmacodynamic properties, but lower incidences of pain on injection, myoclonus and local thrombophlebitis. An additional advantage of the emulsion formulation is its lower osmolality and higher $\mathrm{pH}\left(400 \mathrm{mosmol} \cdot \mathrm{kg}^{-1}\right.$ and $\mathrm{pH}$ 7.6 compared with $4965 \mathrm{mosmol} \cdot \mathrm{kg}^{-1}$ and $\mathrm{pH} 5.1$ for the propylene glycol formation); the former results in less red cell haemolysis. More recently, Doenicke and colleagues have evaluated another etomidate formulation, this time solvented in hydroxypropyl B-cyclodextrin. ${ }^{2}$ Its use was associated with less myoclonia and pain ( $17 \%$ vs $92 \%$; and $8 \%$ vs $58 \%$ ), less thrombophlebitis $(0 \%$ vs $42 \%$ ), and no haemolysis. There were no alterations in the kinetics or dynamics of etomidate. Again the reformulation has a lower osmolality. However none of these reformulations overcome the action of etomidate in inhibiting adrenal steroidogenesis.

For propanidid, a new formulation has been developed to try and overcome the allergenic potential of the solvent micellophor which caused the eugenol to be withdrawn from clinical practice in 1984. However, the drug had a number of important advantages - principally an ultra-short duration of effect due to rapid hydrolysis of the ester linkage by tissue esterases. Complete recovery was seen within one hour of a bolus dose of 5-7 mg.kg-1. Other non-hypnotic effects included excitatory movements in about $10 \%$ of patients, and cardiovascular depression due to negative inotropy, afterload reduction and a delayed response to histamine release.

Habazettl $e t a l$. have recently evaluated a liposomal preparation of propanidid in rats. ${ }^{3}$ At the highest infusion rate $\left(120 \mathrm{mg} \cdot 100 \mathrm{~g} \mathrm{~g}^{-1} \cdot \mathrm{hr}^{-1}\right)$, this formulation (in comparison with the original preparation) caused less cardiorespiratory depression, a decreased incidence of clonic seizures and reduced mortality. Discontinuation of propanidid again resulted in rapid awakening. However, further evaluation in pigs showed this liposomal preparation to have cardiovascular stimulant properties, and to cause increased serum concentrations of histamine, adrenaline and noradrenaline. ${ }^{4}$ Thus it seems unlikely that this reformulation is going to offer much to the clinician.

From the Nuffield Department of Anaesthetics, University of Oxford, John Radcliffe Hospital, Headington, Oxford OX3 9DU. 
The pain associated with propofol administration varies in incidence between 30 and $70 \%$, and can be reduced by pre-treatment with lidocaine, aseptically mixing with lidocaine immediately before dosing, or pre-treatment with fentanyl or alfentanil. More recently it has been shown that addition of LCT (long chain triglyceride) emulsion to propofol (as Diprivan) will reduce the incidence of severe pain from about $70 \%$ to zero. ${ }^{5}$ The mechanism behind this is thought to be due a decrease in the propofol concentration in the aqueous phase secondary to the increase in the fat content. This change in aqueous drug concentration does not seem to influence the kinetics or dynamics of propofol. ${ }^{6}$ Attempts to reformulate propofol in 2hydroxypropyl $\beta$-cyclodextrin have proved unsuccessful as the drug has caused severe bradycardia and hypotension when administered to rats. ${ }^{7}$ Hence again this does not appear to be a viable alternative to the emulsion formulation.

\section{Ketamine}

This phencyclidine derivative has the advantages of being water-soluble, and producing profound analgesia at subanaesthetic doses, while lacking the cardiorespiratory depressive actions of other $i v$ agents. However its usefulness is limited by a high incidence of disturbing emergence reactions (in up to $30 \%$ of patients). Current interest extends to investigation of the relevant potency of the two stereoisomers $[R(-)$ and $S(+)]$. The potency ratio for anaesthesia and analgesia is approximately 4:2:1 for $S(+)$ ketamine: racemic ketamine: $\mathrm{R}(-)$ ketamine. The $S(+)$ isomer produces longer hypnosis compared with the $\mathrm{R}(-)$ isomer at equipotent doses, with the racemate being intermediate. $S(+)$ ketamine (compared with the racemate) causes a lower median EEG power spectrum, a greater rise in blood pressure and heart rate, decreased locomotor activity, shortened recovery times, but equipotent analgesia. ${ }^{8}$ Studies in surgical patients showed the incidence of emergence reactions to be about $37 \%$ after the $\mathrm{R}(-)$ enantiomer, $15 \%$ after the racemate and $5 \%$ after the $S(+)$ isomer. ${ }^{9}$ The incidences of dreaming were the same in the three patient groups.

All three preparations of ketamine cause a comparable depression of the EEG median frequency, but the $\mathrm{IC}_{50}$ [drug concentration of ketamine necessary to achieve a $50 \%$ depression of the maximal EEG median frequency reduction] for $S(+)$ ketamine was considerably less than for $\mathrm{R}(-)$ and the racemate $\left(0.8 \mu \mathrm{g} \cdot \mathrm{ml}^{-1}\right.$ compared with 1.8 and $2.0 \mu \mathrm{g} \cdot \mathrm{ml}^{-1}$ respectively).$^{10} \mathrm{On}$ the basis of an assumed equipotency ratio of $S(+)$ ketamine to racemate of $1: 2$, Geisslinger and colleagues compared the kinetics and dynamics of the enan- tiomers of ketamine in 50 surgical patients. There were no kinetic differences between $S(+)$ ketamine alone and the enantiomer present in the racemic mixture. ${ }^{11}$ However, the $\mathrm{R}(-)$ enantiomer showed a lower clearance and smaller apparent volumes of distribution than the the $S(+)$ enantiomer when administered as one component of the racemate. These data correspond with the in vitro observations showing a faster metabolic degradation of the $S(+)$ isomer; and where the addition of the $\mathrm{R}(-)$ isomer to $\mathrm{S}(+)$ ketamine inhibits the latter's metabolism. ${ }^{12}$ However, in vivo there were no differences in the clearance rates of the $\mathrm{S}(+)$ and $\mathrm{R}(-)$ isomers when given as the racemate. The concentration-effect relationship for $S(+)$ ketamine, therefore, lies to the left of that for the racemate, and it also has a steeper curve.

In man, there are no apparent differences between enantiomers in their cardiovascular effects. However, in vitro, both isomers and the racemate decrease left ventricular contractility and increase $A-V$ conduction time but the $S(+)$ enantiomer has a greater effect than its $\mathrm{R}(-)$ enantiomer in the isolated perfused guinea pig heart. ${ }^{13}$ How does ketamine produce these effects? Both isomers inhibited neuronal and extraneuronal reuptake of catecholamines. There was also central sympathomimetic stimulation, and a direct vasodilatory effect on vascular smooth muscle. However, these effects were stereo-specific, due mainly to the $S(+)$ isomer and we might, therefore, expect a lesser cardiovascular depression from the $\mathrm{S}(+)$ enantiomer. However, in vitro, both isomers decreased the contractile force of a guinea pig heart preparation and in single ventricular guinea pig cells, Sekino $e t$ al. found no difference in the effects of $S(+)$ and $R(-)$ ketamine on trans-sarcolemmal calcium influx via L-type calcium channels. ${ }^{14}$

For clinical utility, the combination of propofol and ketamine by infusion has been found to provide minimal haemodynamic depression at induction, and stability throughout surgery - without psychic disturbances and an absence of postoperative respiratory depression.

\section{New induction agents: steroid anaesthetic agents} and others

\section{Eltanolone}

The anaesthetic properties of $5 \alpha$ - and $5 \beta$-reduced progesterone metabolites are well recognised since the 1940 s, but there has been difficulty in formulating the steroids for $i v$ induction because of their poor water solubility. Previous attempts have included hydroxydione and Althesin (alphaxalone-alphadolone acetate), but both had considerable adverse side-effects. One of the most potent pregnanes was $3 \alpha$-hydroxy, $5 \beta$-pregnan- 
20-one. In 1987, Norberg and colleagues showed in male rats that both $3 \alpha$-hydroxy, $5 \alpha$ - and $5 \beta$ - pregnanolones formulated as an emulsion in Intralipid produced anaesthesia when infused until EEG burst suppression occurred..$^{15}$ However, their use was associated with involuntary excitatory movements (an important side-effect seen during dosing with Althesin and minaxolone). In further experiments in mice, the $5 B$-isomer of pregnanolone was found to have an $\mathrm{ED}_{50}$ for loss of the righting reflex of $3.64 \mathrm{mg} \cdot \mathrm{kg}^{-1}$, compared with $21.8 \mathrm{mg} \cdot \mathrm{kg}^{-1}$ for thiopentone. Induction of anaesthesia was rapid with both drugs, but recovery was faster after pregnanolone at doses of $1.25 \times$ and $5 \times$ the $\mathrm{ED}_{50}$.

When given to healthy male volunteers, pregnanolone emulsion caused anaesthesia with doses of $0.4-0.6 \mathrm{mg} \cdot \mathrm{kg}^{-1}$. Loss of verbal contact occurred before loss of the eyelash reflex (unlike thiopentone). In those studies where there has been an adequate duration of arterial sampling, the disposition of pregnanolone in adults, children and the elderly showed high systemic clearance $\left(1.61-4.40 \mathrm{l} \cdot \mathrm{min}^{-1}\right)$, an elimination half life range of $3.1-4.3 \mathrm{~min}$, and an apparent volume of distribution between 1.20 and $2.301 . \mathrm{kg}^{-1}$. There is a high \% protein binding ( $>99 \%)$ - mainly to albumin. Balance studies recovered $<1 \%$ unconjugated pregnanolone and $7.9-16.2 \%$ as conjugated pregnanolone in the urine over $24 \mathrm{hr}$ after anaesthesia. The main reduced pregnanolone metabolite in man was $5 \beta$-pregnan-3 $\alpha, 20 \alpha$-diol. Total urinary excretion accounted for about $57 \%$ of the steroid, with $28 \%$ appearing in the faeces.

A number of studies defined the $\mathrm{ED}_{50}$ induction dose in benzodiazepine and opioid premedicated patients (between $0.33 \mathrm{mg} \cdot \mathrm{kg}^{-1}$ and $0.44 \mathrm{mg} \cdot \mathrm{kg}^{-1}$ ). As seen with propofol, there was a low incidence of pain on injection; the main side-effects being involuntary movements, mild apnoea and hypertonus. The relative potency of propofol (compared with eltanolone) was 0.313 in benzodiazepine premedicated patients. In all comparative studies, the onset of loss of verbal contact with eltanolone was slower than its comparators, and this would seem to support the findings of Schuttler $e t a l$. who demonstrated a blood-brain equilibration time $\left(\mathrm{t}_{1 / 2}\right.$ $\mathrm{k}_{\mathrm{c}} 0$ ) of 6.9 min. ${ }^{16}$

Detailed cardiovascular effects of eltanolone have been studied in healthy and compromised patients associated with induction of anaesthesia, laryngoscopy and intubation. In benzodiazepine premedicated ASA I and II patients, equipotent induction doses of eltanolone and propofol caused similar haemodynamic responses to induction and intubation, although there was a much greater increase in heart rate after laryngoscopy and intubation in patients receiving eltanolone. ${ }^{17}$ In
ASA II and III patients undergoing coronary artery bypass grafting, eltanolone $\left(0.5-1.0 \mathrm{mg} \cdot \mathrm{kg}^{-1}\right)$ and fentanyl $\left(3 \mu \mathrm{g} \cdot \mathrm{kg}^{-1}\right)$ caused a greater depression of arterial pressure when compared with fentanyl and thiopentone $\left(3 \mathrm{mg} \cdot \mathrm{kg}^{-1}\right) \cdot{ }^{18}$ However, cardiac output was unaltered after eltanolone, suggesting it had a greater effect on SVR than on contractility. There was also a reduction in PCWP and LVSWI.

Other features of eltanolone include low incidences of pain to injection, and postoperative nausea and vomiting. The respiratory effects of eltanolone (in keeping with other steroid induction agents) were less depressive than those seen with other $i v$ induction agents. In a study of 76 unpremedicated patients, ventilatory performance was measured after bolus doses of eltanolone $\left(0.75 \mathrm{mg} \cdot \mathrm{kg}^{-1}\right)$, thiopentone $\left(4.0 \mathrm{mg} \cdot \mathrm{kg}^{-1}\right)$ or propofol $\left(2.5 \mathrm{mg} \cdot \mathrm{kg}^{-1}\right)$. After breathing $35 \%$ oxygen for three minutes, subjects received the $i v$ hypnotic agent over 30 sec and tidal volume and respiratory rate were continuously recorded by respiratory inductance plethysmography and a pneumotachograph. ${ }^{19}$ The overall incidences of apnoea were $57 \%$ for eltanolone, $74 \%$ for thiopentone and $100 \%$ for propofol. Apnoea of greater than 30 sec occurred in $30 \%$ of patients receiving eltanolone, $39 \%$ with thiopentone and $74 \%$ with propofol. The duration of this apnoea was least with eltanolone and greatest with propofol. The changes in rib-cage and abdominal components of ventilation were similar for all three induction agents. Thus, eltanolone appeared to be less ventilatory depressant than propofol, and to be comparable with thiopentone. There are presently no available data on whether eltanolone affects the central control of respiration.

There have been few data on the use of eltanolone by incremental dosing or infusion to supplement either nitrous oxide or opioid anaesthesia. Using increments of eltanolone to supplement nitrous oxide, maintenance requirements ranged between 0.015 and 0.025 $\mathrm{mg} \cdot \mathrm{kg}^{-1} \cdot \mathrm{min}^{-1}$. However, a decision has recently been taken by Pharmacia-Upjohn to discontinue the evaluation of eltanolone because of a higher than anticipated incidence of urticaria, and no significant improved efficacy compared with other iv. induction agents.

\section{Water-soluble amino-steroids}

Because of the difficulty in finding suitable solvents for water-insoluble steroids, Figdor and colleagues examined the properties of both pregnane and androstane esters and found that amino-esters of 21hydroxypregnanedione were both water-soluble and caused loss of the righting reflex in animals. ${ }^{20}$

The first important water-soluble agent was minaxolone citrate. Its main undesirable features were the 
high incidence of excitatory side-effects during induction, increased muscle tone intra-operatively, and involuntary movements during recovery. The latter was often prolonged. Minaxolone was withdrawn from clinical studies in September 1979 because of these adverse features, concern over toxicological effects of large doses in rats, and an absence of any clear advantage over the other agents available in clinical practice at that time.

Two new water-soluble steroid hypnotic agents have recently been evaluated by Organon. Gemmell and colleagues described the anaesthetic properties in the mouse, rat and dog of a water-soluble 2 -substituted aminosteroid (ORG 20599). ${ }^{21}$ This appeared to have an efficacy similar to that of Althesin, a high therapeutic index of 13 and to be associated with an hypnotic effect of short duration. However, this has not been evaluated in man because of problems relating to the stability and solubility of the methanesulphonate salt. Another 2-substituted aminosteroid has also been evaluated in animals and in man (ORG 21465: base; ORG 21256: citrate salt). ${ }^{22}$ Again, this steroid shows a high therapeutic index in mice (13.8) when compared with propofol or thiopentone (4-5). In the monkey, ORG 21465 has been compared with propofol in doses of 4 and $3 \mathrm{mg} \cdot \mathrm{kg}^{-1}$ respectively. Both showed rapid onset of hypnosis, but the duration of sleep and of recovery was slower with the aminosteroid. In the dog, the effective hypnotic induction dose of ORG 21465 was $3 \mathrm{mg} \cdot \mathrm{kg}^{-1}$ and maintenance doses were $2.8 \mu \mathrm{mol} \cdot \mathrm{kg}^{-1} \cdot \mathrm{min}^{-1}$; giving a potency ratio of $1: 8$ with respect of propofol. Preliminary data from human volunteers was less reassuring. Doses in excess of $1 \mathrm{mg} \cdot \mathrm{kg}^{-1}$ caused loss of consciousness within one minute in unpremedicated subjects, and the duration of effect was dose-dependent over the range 1.0-1.8 $\mathrm{mg} \cdot \mathrm{kg}^{-1}$. However, as with many of the other steroids investigated in man, there was a high incidence (70\%) of excitatory side-effects - although no accompanying EEG spike activity. Although again there was an absence of cardiovascular and respiratory depression, it is uncertain whether this drug will be evaluated further in man.

\section{Other new hypnotic agents}

There has been a recent evaluation of two water-soluble imidazo-benzodiazepines (Ro 48-6791 and Ro 48-8684). In comparison with midazolam, both show a higher clearance ( 1.48 and $1.68 \mathrm{l} \cdot \mathrm{min}^{-1}$ respectively) and larger volumes of distribution. ${ }^{23}$ All three drugs have an elimination half life of 180-210 min. The $\mathrm{IC}_{50}$ values for $50 \%$ maximal EEG depression are $62(28)$ $\mathrm{ng} \cdot \mathrm{ml}^{-1}$ and $277 \pm 147 \mathrm{ng} \cdot \mathrm{ml}^{-1}$ for the newer agents, and $531 \pm 221 \mathrm{ng} \cdot \mathrm{ml}^{-1}$ for midazolam. The $\mathrm{t}_{1 / 2} \mathrm{k}_{\mathrm{c}} 0$ values are smaller for the newer agents, and recovery was also correspondingly faster.

\section{New medical technologies for induction of anaesthesia}

The development of 'Target Controlled Infusion (TCI)' technology is based on our understanding of a drug's kinetic and dynamic properties. Instead of titrating the dose of an intravenous induction agent by incremental boluses until loss of verbal contact or the eyelash reflex, the anaesthetist chooses a 'target drug concentration' at which anaesthesia has been found to occur in comparable patient groups.

A number of TCI systems are currently under development for both hypnotic and analgesic drugs; one proprietary system has recently been introduced in the UK for propofol ('Diprifusor' TCI; Zeneca). ${ }^{24}$ With this system, the blood concentration is the targetted value, but the target site could also be the concentration in the 'biophase' or effector site in the brain.

Preliminary clinical evaluation of the 'Diprifusor' TCI shows the system to underpredict the actual blood concentration, with a MDAPE of around $20-25 \%$, and an MDPE of $16 \%$. These performance errors reflect inter-individual kinetic variability. Similar under-predictions of the measured blood concentrations have also been found for manual infusion systems (mean PD 17-22\%; mean APE $25-30 \%$ ). ${ }^{25}$ With all kinetically driven infusion regimens, the predictability will be influenced by the appropriateness of the input kinetic data set to the clinical scenario under investigation.

To date, there are few published data on the quality of induction or maintenance with the 'Diprifusor', or comparisons with other delivery systems; these are eagerly awaited. However unpublished reports suggest that TCI may improve induction times and reduce the number of responses to the initial incision, or other surgical stimuli during the maintenance phase. Haemodynamic effects appear comparable with those during manual infusion regimens for propofol delivery. Future randomised double-blind trials are needed to support these early clinical data.

\section{References}

1 Westrin $P$, Jonmarker $C$, Werner $O$. Dissolving methohexital in a lipid emulsion reduces pain associated with intravenous injection. Anesthesiology 1992; 76: 930-4.

2 Doenicke A, Roizen MF, Nebauer AE, Kugler A, Hoernecke R, Beger-Hintzen $H$. A comparison of two formulations of etomidate, 2-hydroxypropyl- $B$ cyclodextrin (HPCD) and propylene glycol. Anesth Analg 1994; 79: 933-9. 
3 Habazettl H, Vollmar B, Röhrich F, Conzen P, Doenicke $A$, Baethmann $A$. Anaesthetic potency of a liposomal propanidid preparation. Experimental studies in rats. (German) Anaesthesist 1992; 41: 448-56.

4 Klockgether-Radke A, Kersten J, Schröder T, Stafforst D, Kettler D, Hellige G. Anästhesie mit propanidid in liposomaler zubereitung. Eine experimentelle studie am schwein. Anaesthesist 1995; 44: 573-80.

5 Doenicke AW, Roizen MF, Rau J, Kellermann W, Babl $J$. Reducing pain during propofol injection: the role of the solvent. Anesth Analg 1996; 82: 472-6.

6 Doenicke A, Roizen MF, Rau J, Kugler J. Two different solvents for propofol: is hypnotic effect different? Anesth Analg 1996; 82: \$94.

7 Bielen SJ, Lysko GS, Gough WB. The effect of a cyclodextrin vehicle on the cardiovascular profile of propofol in rats. Anesth Analg 1996; 82: 920-4.

8 White PF, Schüttler J, Shafer A, Stanski DR, Horai $\Upsilon$, Trevor AJ. Comparative pharmacology of the ketamine isomers. Br J Anaesth 1985; 57: 197-203.

9 White PF, Ham J, Way WL, Trevor AJ. Pharmacology of ketamine isomers in surgical patients. Anesthesiology 1980; 52: 231-9.

10 Schüttler J, Stanski DR, White PF, et al. Pharmacodynamic modeling of the EEG effects of ketamine and its enantiomers in man. J Pharmacokinet Biopharm 1987; 15: 241-53.

11 Geisslinger G, Hering W, Thomann P, Knoll R, Kamp $H-D$, Brune $K$. Pharmacokinetics and pharmacodynamics of ketamine enantiomers in surgical patients using a stereoselective analytical method. Br J Anaesth 1993; 70: 666-71.

12 Kharasch ED, Labroo R. Metabolism of ketamine stereoisomers by human liver microsomes. Anesthesiology 1992; 77: 1201-7.

13 Graf BM, Vicenzi MN, Martin E, Bosnjak ZJ, Stowe $D F$. Ketamine has stereospecific effects in the isolated perfused guinea pig heart. Anesthesiology 1995; 82: 1426-37.

14 Sekino N, Endou M, Hajiri E, Okumura $F$. Nonstereospecific actions of ketamine isomers on the force of contraction, spontaneous beating rate, and $\mathrm{Ca}^{2+}$ current in the guinea pig heart. Anesth Analg 1996; 83: 75-80.

15 Norberg L, Wahlström G, Bäckström T. The anacsthetic potency of $3 \alpha$-hydroxy-5 $\alpha$-pregnan-20-one and $3 \alpha$ hydroxy-5B-pregnan-20-one determined with an intravenous EEG-threshold method in male rats. Pharmacol Toxicol 1987; 61: 42-7.

16 Schüttler J, Hering W, Ibmsen $H$, Geisslinger $G$, $R$ ügheimer E. Pharmacokinetic/-dynamic modeling of the new intravenous anesthetic eltanolone.

Anesthesiology 1994; 81: A409.
17 Sear JW, Jewkes C, Wanigasekera V. Hemodynamic effects during induction, laryngoscopy, and intubation with eltanolone (5B-pregnanolone) or propofol. A study in ASA I and II patients. J Clin Anesth 1995; 7: 126-31.

18 Tassani P, Jänicke U, Ott E, Grob J, Conzen P. Hemodynamic effects of anesthetic induction with eltanolone-fentanyl versus thiopental-fentanyl in coronary artery bypass patients. Anesth Analg 1995; 81: 469-73.

19 Spens HJ, Drummond GB, Wraith PK. Changes in chest wall compartment volumes on induction of anaesthesia with eltanolone, propofol and thiopentone. $\mathrm{Br}$ J Anaesth 1996; 76: 369-73.

20 Figdor SK, Kodet MJ, Bloom BM, Agnello EJ, P'An SY, Laubach $G D$. Central activity and structure in a series of water-soluble steroids. J Pharmacol Exp Ther 1957; 119: 299-309.

21 Gemmell $D K$, Campbell $A C$, Anderson A, Byford $A$, Hill-Venning $C$, Marshall RJ. ORG 20599: a new water soluble aminosteroid intravenous anaesthetic. $\mathrm{Br}$ J Pharmacol 1994: 111(Suppl): 189P

22 Gemmell $D K$, Byford $A$, Anderson $A$, et al. The anaesthetic and GABA modulatory actions of ORG 21465 , a novel water soluble steroidal intravenous anaesthetic agent. Br J Pharmacol 1995; 116(Suppl): 443P.

23 Ibmsen $H$, Hering $W$, Albrecht $S$, et al. Pharmacokinetics of the new benzodiazepines RO 48 6791 and RO 48-8684 in comparison with midazolam in young and elderly volunteers. Anesthesiology 1996; 85: A317.

24 White $M$, Kenny $G N C$. Intravenous propofol anaesthesia using a computerised infusion system. Anaesthesia 1990; 45: 204-9.

25 Sear JW, Glen JB. Propofol administered by a manual infusion regimen. $\mathrm{Br} \mathrm{J}$ Anaesth 1995; 74: 362-7. 


\title{
Les nouveaux agents d'induction
}

\author{
J.W. Sear MA BSc PhD FFARCS FANZCA
}

P LUSIEURS nouveaux produits et présentations d'anesthésiques intraveineux sont présentement à l'essai. L'objectif qui consiste à trouver des agents dont les propriétés se rapprochent de l'idéal demeure à l'ordre du jour (Tableau I). En outre, pour délivrer ces hypnotiques, l'anesthésiste a maintenant accès à une toute nouvelle technologie.

TABLEAU Propriétés de l'anesthésique intraveineux idéal

\begin{tabular}{l}
\hline Propriétés physiques \\
Hydrosoluble \\
Stable en solution \\
Se conservant longtemps \\
Non douloureux à l'injection \\
Non irritant en sous-cutané \\
Petites doses intra-artérielles inoffensives \\
Faible incidence de thrombose veineuse \\
Petit volume en solution isotonique requis pour l'induction \\
Propriétés pharmacologiques \\
Dépression cardiorespiratoire minime \\
Non histanninogène \\
Induction dans un seul temps de circulation bras-cerveau \\
Dégradé en métabolites inactifs \\
Pas de blocage myoneural
\end{tabular}

\section{Nouvelles présentations}

Méthohexitone, étomidate, propanidid et propofol

Les émulsions lipidiques servent normalement à préparer des produits insolubles dans l'eau ; cependant elles peuvent aussi être utilisées comme vecteurs de composés hydrophiles responsables d'effets secondaires importants comme la douleur à l'injection (le méthohexitone) ou la douleur à l'injection compliquée de séquelles veineuses (étomidate). Dans une étude réalisée chez des volontaires, Westrin et al. ont comparé le méthohexitone en solution aqueuse avec une émulsion de ce barbiturique. ${ }^{1}$ L'incidence des douleurs à l'injection rapportées spontanément a chuté de $83 \%$ à zéro, et les échelles visuelles analogiques, de $38 \mathrm{~mm}$ à $5 \mathrm{~mm}$. Au cours d'une évaluation ultérieure réalisée chez 42 patients non prémédiqués subissant différentes intervention chirurgicales, $\mathrm{l}^{\prime} \mathrm{ED} \mathrm{D}_{50}$ (la dose hypnotique provoquant la perte de conscience chez $50 \%$ des sujets) pour l'émulsion était $1,2 \pm 0,1 \mathrm{mg} \cdot \mathrm{kg}^{-1}$ pour l'émulsion et $1,1 \pm 0,1 \mathrm{mg} \cdot \mathrm{kg}^{-1}$ pour la solution aqueuse. Ce qui démontre que le changement de préparation ne modifiait pas la puissance $d$ l'agent.

Avec l'émulsion lipidique d'étomidate, on n'a pas démontré que les propriétés pharmacodynamiques changeaient alors que l'incidence des douleurs à l'injection, des myoclonies et des thrombophlébites locales diminuait. L'osmolalité inférieure et le $\mathrm{pH}$ plus élevé (400 mosmol $\cdot \mathrm{kg}^{-1}$ et un $\mathrm{pH}$ de 7,6 comparativement à $4965 \mathrm{mosmol} \cdot \mathrm{kg}^{-1}$ et un $\mathrm{pH}$ de 5,1 pour la préparation au propylène glycol) constituent un avantage supplémentaire pour l'émulsion; la dernière préparation provoque en effet moins d'hémolyse. Plus récemment, Doenicke et al. ont évalué une nouvelle formule d'étomidate utilisant cette fois comme solvant l'hydroxypropyl—cyclodextrin. ${ }^{2}$ Son utilisation s'accompagnait de moins de myoclonies et de douleur ( $17 \%$ ps $92 \%$ et $8 \%$ vs $58 \%$ ), de moins de thrombophlébite ( $0 \%$ vs $42 \%$ ) et d'aucune hémolyse. Ni la cinétique ni la dynamique de l'étomidate n'était altérée. L'osmolalité de cette nouvelle formule était aussi plus basse. Cependant, aucune des nouvelles formules n'abolissait l'effet inhibiteur de l'étomidate sur la stéroïdogénèse adrénalienne.

En ce qui concerne le propanidid, une nouvelle formule a été élaborée dans le but de maîtriser le potentiel allergénique du solvant micellophor qui a forcé le retrait de l'eugénol de la pratique clinique en 1984. Cet agent possédait toutefois un certain nombre d'avantages importants, dont une durée d'action ultracourte due à l'hydrolyse rapide de la liaison ester par les estérases tissulaires. La récupération complète survenait en moins d'une heure après une dose en bolus de 5 à $7 \mathrm{mg} \cdot \mathrm{kg}^{-1}$. L'agent produisait quatre effets secondaires sans rapport avec l'hypnose: des mouvements d'excitation chez environ $10 \%$ des sujets, une dépression cardiovasculaire par inotropisme négatif, une réduction de la postcharge et une réponse histaminique retardée.

Bazezettl $e t a l$. ont récemment évalué une préparation liposomique de propanidid chez le rat. ${ }^{3}$ Lorsque la vitesse de perfusion était à son plus haut niveau, (120 mg. $100 \mathrm{~g}^{-1} \cdot \mathrm{h}^{-1}$ ), cette formule (comparativement à la préparation originale) a entraîné moins de dépression cardiovasculaire, diminué l'incidence des convulsions toniques et provoqué une baisse de la mortalité. L'arrêt du propanidid procurait toujours un réveil 
rapide. Cependant, une évaluation ultérieure sur le porc a montré que cette préparation liposomique avait des propriété cardiovasculaires stimulantes et augmentait les concentrations sériques d'histamine, d'adrénaline et de noradrénaline. ${ }^{4}$ Il semble peu probable que cette nouvelle formule ait quelque avantage que ce soit en clinique.

L'incidence de la douleur au moment de l'administration du propofol varie entre 30 et $70 \%$ et peut être réduite par l'administration préalable de lidocaïne, par le mélange aseptique de la lidocaïne au propofol ou par le prétraitement au fentanyl ou au sufentanil. Plus récemment, on a montré que l'ajout d'une émulsion de LCT (un triglycéride à longue chaine) au propofol (Diprivan) diminuait l'incidence de la douleur de $70 \%$ à aucune. ${ }^{5}$ On croit que cette amélioration est causée par la diminution de la concentration de propofol en phase aqueuse secondaire à l'augmentation du contenu lipidique. Ce changement de concentration aqueuse du propofol ne semble pas influencer sa cinétique ni sa dynamique. ${ }^{6}$ Les tentatives de préparation du propofol dans l'hydroxyl $B$-cyclodextrine ont mal tourné car le nouveau composé provoquait une bradycardie et une hypotension graves lorsqu'il était administré à des rats ${ }^{7}$; cette nouvelle formule ne semble donc une alternative susceptible de remplacer l'émulsion.

\section{La kétamine}

Ce dérivé de la phencyclidine a l'avantage d'être hydrosoluble et de produire une analgésie profonde à des doses hypoanesthésiques sans avoir les propriétés cardiorespiratoires dépressives des autre agents ip. Toutefois, la kétamine provoque une incidence élevée de réactions inopportunes à la phase du réveil (jusque chez $30 \%$ des patients). La puissance des deux stéréoisomères $[R(-)$ et $S(+)]$ est présentement à l'étude. Pour l'anesthésie et l'analgésie, le ratio de puissance est respectivement d'environ 4:2:1 pour la $S(+)$ kétamine: kétamine racémique: $\mathbf{R}(-)$ kétamine. L'isomère $S(+)$ produit une hypnose plus prolongée que l'isomère $R(-)$ à des doses équipotentes, alors que le racémate se situe entre les deux. La kétamine $S(+)$ (comparée au racémate) montre une puissance spectrale médiane ÉEG inférieure, une élévation plus importante de la pression artérielle et de la fréquence cardiaque, une diminution de l'activité locomotrice, une réduction de la phase d'éveil plus courte tout en maintenant une puissance analgésique identique. ${ }^{8}$ Des études réalisées en chirurgie, ont montré qu'à la phase de réveil, l'incidence des réaction était d'environ $37 \%$ avec l'énantiomère $\mathrm{R}(-)$, de $15 \%$ avec le racémate et de $5 \%$ avecl'isomère $S(+) .{ }^{8}$ L'incidence de l'onirisme était la même dans les trois groupes.
Les trois préparations de kétamine produisent une dépression comparable de la fréquence ÉEG médiane, mais l' $\mathrm{IC}_{50}$ [la concentration de kétamine nécessaire pour provoquer une baisse de $50 \%$ de la fréquence médiane ÉEG maximale] de la kétamine $S(+)$ était beaucoup plus basse avec $R(-)$ et le racémate $(0,8$ $\mu \mathrm{g} \cdot \mathrm{ml}^{-1}$ comparativement à 1,8 et à $\left.2,0 \mu \mathrm{g} \cdot \mathrm{ml}^{-1}\right) \cdot{ }^{10}$ Sur la base d'un ratio d'équipotence présumée de $1: 2$ de la kétamine $S(+)$ avec le racémate, Geisslinger et al. ont comparé la cinétique et la dynamique des énantiomères de la kétamine chez $\mathbf{5 0}$ patients. Ils n'ont pas trouvé de différence en ce qui concerne la cinétique entre la kétamine $S(+)$ seule et l'énantiomère présent dans le mélange racémique." Cependant, l'énantiomère $R(-)$ avait une clairance plus basse et des volumes de distribution apparents plus faibles que l'énantiomère $S(+)$ lorsqu'il était administré comme un composé du racémate. Ces données correspondent aux observations in vitro qui révèlent une dégradation métabolique plus rapide de l'isomère $S(+)$ et que l'addition de l'isomère $R(-)$ à la kétamine $\left(S_{+}\right)$inhibe le métabolisme de celle-ci. ${ }^{12}$ Cependant, in vivo, on n'a pas trouvé de différence en ce qui concerne les taux de clairance des isomères $S(+)$ et $R(-)$ quand ils sont administrés comme le racémate. La relation concentration-effet pour la kétamine $S(+)$ se situe donc à gauche de celle du racémate et a aussi une courbe plus prononcée.

Chez l'humain, il n'y a pas de différences d'effets cardiovasculaires apparentes entre les énantiomères. Toutefois, in vitro, les deux isomères et le racémate diminuent la contractilité ventriculaire gauche et augmentent le temps de conduction a-v mais l'énantiomère $S(+)$ a un effet plus prononcé que l'énantiomère $R(-)$ sur le coeur perfusé de cobaye. ${ }^{13}$ Comment la kétamine produit-elle ces effets ? Les deux isomères inhibent le recaptage neural et extraneural des catécholamines. On a aussi noté une stimulation sympathicomimétique centrale et une activité vasodilatatrice directe sur le muscle vasculaire lisse. Cependant, ces effets étaient stéréospécifiques, dus principalement à l'isomère $S(+)$ et nous pourrions donc nous attendre à une dépression cardiovasculaire moins importante de la part de l'énantiomère $S(+)$. Cependant, in vitro, les deux isomères diminuaient la force contractile de la préparation de coeur de cobaye et des cellules isolées de ventricule gauche du même animal. Sekino et al. n'ont pas trouvé de différence en ce qui concerne les effets de la kétamine $S(+)$ et $R(-)$ sur l'influx de calcium a travers le sarcolemme par les canaux calciques de type L. ${ }^{14}$

Cliniquement, la combinaison de propofol et de kétamine en perfusion n'a produit qu'une dépression hémodynamique minime à l'induction, et le maintien 
de la stabilité pendant la chirurgie, sans perturbation psychique ni dépression respiratoire postopératoire.

Les nouveaux agents d'induction: les anesthésiques stéroïdes et les autres L'eltanolone

Les propriétés anesthésiques des métabolites réduits $5 \alpha$ et $5 \beta$ du progestérone sont bien connus depuis les années 40 , mais il a été difficile de trouver une nouvelle formule de stéroïde pour l'induction iv à cause de leur faible solubilité aqueuse. Les tentatives antérieures portaient sur l'hydroxydione et l'Altésine (acétate d'alphaxalone-alphadolone) mais les deux avaient des effet secondaires importants. Un des prégnanes les plus puissants était le $3 \alpha$-hydroxy, 5ß-prégnane-20 $\alpha$-one. En 1987, Norberg et al. ont montré chez des rats mâles que les deux $3 \alpha$-hydroxy, $5 \alpha$ et $5 \beta$ prégnanolones préparés en émulsion dans d'intralipid produisait l'anesthésie jusqu'au «burst suppression» de l'ÉEG. ${ }^{15}$ Leur administration était toutefois associée à des mouvements d'excitation (un effet secondaire important de l'Altésine et du minaxolone). Des expériences subséquentes sur la souris ont montré que l'isomère $5 \mathrm{du}$ prognanolone avait une $\mathrm{ED}_{50}$ de $2,64 \mathrm{mg} \cdot \mathrm{kg}^{-1}$ pour le réflexe de redressement comparativement à $21,8 \mathrm{mg} \cdot \mathrm{kg}^{-1}$ pour le thiopentone. L'induction de l'anesthésie avec les deux agents était rapide mais le réveil était plus rapide avec le prégnanolone à des doses de 1,25 fois et 5 fois $\mathrm{l}^{\prime} \mathrm{ED}_{50}$.

Administrée à des volontaires bien portants de sexe masculin, l'émulsion de prégnanolone a produit l'anesthésie à des doses variant de 0,4 à $0,6 \mathrm{mg} \cdot \mathrm{kg}^{-1}$. La perte du contact verbal survenait avant celle du réflexe palpébral (contrairement au thiopentone). Des études qui comportaient une durée d'échantillonnage artériel adéquate, la disposition du prégnanolone chez des adultes, des enfants et des personnes âgées révélaient une clairance systémique élevée $(1,61$ à 4.40 $\mathrm{L} \cdot \mathrm{min}^{-1}$ ) une demi-vie d'élimination de 3 , à $4,3 \mathrm{~min}$ et un volume de distribution apparent situé entre 1,23 et $2,30 \mathrm{~L} \cdot \mathrm{kg}^{-1}$. Le pourcentage de liaison aux protéines et principalement à l'albumine est élevé (>99\%). Des études d'équilibre ont récupéré moins de $1 \%$ du prégnanolone non conjugé et de 7,9 à 16,2 du prognanolone conjugé dans l'urine après une anesthésie de plus de $24 \mathrm{~h}$. Le métabolite principal de la réduction du prégnanolone chez l'humain était le $5 ß$-prégnane-3 $\alpha, 20 \alpha$-diol. L'excrétion urinaire totale comptait pour environ $57 \%$ du stérö̈de dont $28 \%$ apparaissait dans les selles.

Certaines études ont établi la dose d'induction $\mathrm{ED}_{50}$ chez des patients prémédiqués aux benzodiazépines et aux morphiniques (entre $0,33 \mathrm{mg} \cdot \mathrm{kg}^{-1}$ et $0,44 \mathrm{mg} \cdot \mathrm{kg}^{-1}$ ). Comme avec le propofol, l'incidence de la douleur à l'in- jection était faible et les effets secondaires principaux se manifestaient par des mouvements involontaires, de l'apnée et de l'hypertonie légères. La puissance relative du propofol (comparée à celle de l'eltanolone) était 0,313 chez des patients prémédiqués aux benzodiazépines. Dans toutes les études comparatives, la perte du contact verbal débutait plus lentement avec l'eltanolone qu'avec les produits auxquels on la comparait, ce qui semble appuyer les données de Schttler et al. qui ont trouvé que le temps d'équilibration hématoencéphalique $\left(\mathrm{t}_{1 / 2} \mathrm{k}_{\mathrm{c}} 0\right)$ était $6,9 \mathrm{~min} .{ }^{16}$

Les effets propres à l'eltanolone ont été étudiés à l'induction de l'anesthésie, à la laryngoscopie et à l'intubation chez des sujets en bonne santé et chez des malades. Chez des patients ASA I et II prémédiqués aux benzodiazépines, des doses d'induction équipotentes d'eltanolone et de propofol ont produit les mêmes réactions hémodynamiques à l'induction et à l'intubation bien que l'augmentation de la fréquence cardiaque ait été plus marquées chez ceux qui avaient reçu de l'eltanolone. ${ }^{17}$ Chez des patients ASA II et III soumis à une chirurgie de revascularisation myocardique, l'eltanolone $\left(0,5\right.$ à $\left.1,0 \mathrm{mg} \cdot \mathrm{kg}^{-1}\right)$ et le fentanyl $\left(3 \mu \mathrm{g} \cdot \mathrm{k}^{-1}\right)$ ont provoqué une baisse plus importante de la pression artérielle comparativement au fentanyl et au thiopentone ( $\left.3 \mathrm{mg} \cdot \mathrm{kg}^{-1}\right) \cdot{ }^{18}$ Cependant, le débit cardiaque n'était pas modifié par l'eltanolone, ce qui lui donne une influence plus importante sur la résistance vasculaire périphérique que sur la contractilité. La pression capillaire bloquée et l'index du travail du ventricule gauche étaient aussi diminués.

Les autres caractéristiques de l'eltanolone comprennent une faible incidence de douleur à l'injection, et de nausées et vomissements postopératoires. Les effets dépressifs de l'eltanolone sur la respiration (comparés aux autres stéroïdes administrés pour l'induction) étaient moins importants que ceux que provoquaient les autres agents d'induction iv. $\mathrm{Au}$ cours d'une étude regroupant 76 patients non prémédiqués, l'efficacité de la ventilation a été évaluée après des doses en bolus d'eltanolone $\left(0,75 \mathrm{mg} \cdot \mathrm{kg}^{-1}\right)$, de thiopentone $\left(4 \mathrm{mg} \cdot \mathrm{kg}^{-1}\right)$ et de propofol $(2,5$ $\left.\mathrm{mg} \cdot \mathrm{kg}^{-1}\right)$. Après avoir respiré de l'oxygène à $35 \%$ pendant trois minutes, les sujets ont reçu l'agent hypnotique en $30 \mathrm{sec}$ alors que le volume courant et la fréquence respiratoire étaient enregistrés continuellement avec un pléthysmographe par inductance et un pneumotacographe. ${ }^{19}$ L'incidence globale d'apnée était de $57 \%$ pour l'eltanolone, de $74 \%$ pour le thiopentone et de $100 \%$ pour le propofol. Une apnée se prolongeant pour plus de $30 \mathrm{sec}$ survenait chez $30 \%$ des patients sous eltanolone, $39 \%$ sous thiopentone et $74 \%$ sous propofol. La durée de cette apnée était la 
plus courte avec l'eltanolone et la plus longue avec le thiopentone. Les changements enregistrés au niveau des composantes thoracique et abdominale de la ventilation étaient les mêmes pour les trois agents d'induction. Ainsi, l'eltanolone semble déprimer moins la ventilation que le propofol et sous cet aspect l'altanolone est comparable au thiopentone. Les données actuellement disponibles ne permettent pas de déterminer si l'eltanolone exerce une influence sur le contrôle central de la respiration.

Nous ne possédons que très peu de données sur l'utilisation de doses progressives ou d'une perfusion d'eltanolone administrée pour renforcer l'anesthésie au protoxyde d'azote ou aux morphiniques. Avec l'utilisation de doses fractionnées d'eltanolone pour complémenter l'anesthésie au protoxyde d'azote, les doses se situaient entre 0,015 et $0,025 \mathrm{mg} \cdot \mathrm{kg}^{-1} \cdot \mathrm{min}^{-1}$ pour le maintien de l'anesthésie. Néanmoins, la compagnie Pharmacia-Upjohn a dernièrement pris la décision de discontinuer l'évaluation de l'eltanolone à cause de l'incidence plus importante qu'anticipée d'urticaire et parce que l'eltanolone ne semble pas plus efficace que les autres agents d'induction $i v$.

\section{Les aminostéroïdes hydrosolubles}

Comme il était difficile de trouver des solvants acceptables pour les stéroïdes solubles dans l'eau, Figdor $e t$ $a l$. ont étudié les propriétés des esters du prégnane et de l'androstane et trouvé que ces esters aminés du 21 hydroxypregnandione étaient tous deux hydrosolubles et provoquaient la perte du réflexe de redressement chez les animaux. ${ }^{20}$

Le premier agent hydrosoluble étudié a été le citrate de minaloxone. Il possédait certaines caractéristiques défavorables dont une incidence élevée d'excitation pendant l'induction, et une augmentation peropératoire du tonus musculaire et des mouvements involontaires et une phase de réveil souvent prolongée. Les études cliniques sur le minaloxone ont finalement cessé en septembre 1979 à cause de ces caractéristiques désavantageuses, la crainte de la toxicité des doses élevées déjà démontrée chez le rat, et l'absence d'avantages réels sur les autres agents disponibles en clinique à ce moment-là.

Organon évalue présentement deux nouveaux stéroïdes hypnotiques. Gemmell $e t$ al. ont décrit les propriétés anesthésiques d'un aminostérö̈de 2-substitué hydrosoluble (RG20599). ${ }^{21}$ Son efficacité semble identique à celle de l'Altésine, avec un index thérapeutique de 13 associé à des effets hypnotiques de courte durée. Ce produit n'a pas été évalué chez l'humain à cause de du manque de stabilité et de solubilité du sel méthanesulphonate. Un autre aminostéroïde 2 -substi- tué a aussi été évalué chez l'animal et chez l'humain (ORG 21465: base; ORG 21256: sel citrate). ${ }^{22} \mathrm{Ce}$ stéroïde a lui aussi un index thérapeutique élevé chez la souris $(13,8)$ lorsqu'on le compare au propofol et au thiopentone (4 à 5). Chez le singe, ORG 21465 a été comparé au propofol à des doses de 4 et de 3 $\mathrm{mg} \cdot \mathrm{kg}^{-1}$. Dans les deux cas, le début d'action état rapide, mais la durée du sommeil et de la phase de réveil se prolongeaient avec l'aminostéroïde. Chez le chien, la dose d'induction efficace de l'ORG 21465 était de $3 \mathrm{mg} \cdot \mathrm{kg}^{-1}$ et d'entretien de $2,8 \mu \mathrm{mol} \cdot \mathrm{kg}^{-1} \cdot \mathrm{min}^{-1}$, ce qui donnait un rapport de puissance de 1:8 comparativement au propofol. Les données préliminaires recueillies chez des volontaires étaient moins rassurantes. Les doses plus élevées que $1 \mathrm{mg} \cdot \mathrm{kg}^{-1}$ produisait une perte de conscience en moins d'une minute chez des sujets non prémédiqués et la durée de l'effet était proportionnelle à la dose entre 1,0 et $1,8 \mathrm{mg} \cdot \mathrm{kg}^{-1}$. Cependant, comme pour plusieurs autres stéroïdes étudiés chez l'humain, l'incidence des phénomènes d'excitation était élevée (70\%) bien que l'ÉEG n'ait pas enregistré de pointes-ondes. Bien qu'on ait pas constaté de dépression respiratoire et cardiovasculaire, il n'est pas certain que ce produit sera évalué de façon plus élaborée chez l'homme.

\section{Les autres hypnotiques récents}

On a récemment évalué deux imidazo-benzodiazépines hydrosolubles (Ro 48-6791 et Ro 48-8684). Comparativement au midazolam, ces deux produits possèdent une clairance plus élevée (respectivement 1,48 et 1,68 L. $\mathrm{min}^{-1}$ ) et de plus grands volumes de distribution. ${ }^{23}$ Les trois agents (incluant le midazolam) ont une demi-vie d'élimination de 189 à $210 \mathrm{~min}$. Les valeurs de

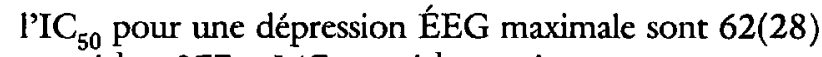
$\mathrm{ng} \cdot \mathrm{ml}^{-1}$ et $277 \pm 147 \mathrm{ng} \cdot \mathrm{ml}^{-1}$ pour les nouveaux agents et $531 \pm 221 \mathrm{ng} \cdot \mathrm{ml}^{-1}$ pour le midazolam. Les valeurs de $t_{1 / 2} k_{e} 0$ sont plus basses pour les nouveaux agents ce qui correspond à un réveil plus rapide.

\section{Les nouvelles technologies médicales pour l'induction de l'anesthésie}

Le développement de la perfusion contrôlée ciblée (Target Ccontrolled Infusion : TCI) est basé sur notre connaisssance des propriété cinétiques et dynamiques des agents. Plutôt que de titrer un agent d'induction en bolus répétés jusqu'à la perte du contact verbal ou du réflexe palpébral, l'anesthésiste choisit une «concentration-cible» produisant l'anesthésie chez un groupe de patients comparables.

Un certain nombre de systèmes TCI font l'objet d'études tant pour les anesthésiques que pour les hypnotiques : un système spécifique au propofol a été 
introduit au Royaume-Uni («Diprifusor» TCI; Zeneca). ${ }^{24}$ Avec ce système, la concentration plasmatique représente la valeur cible, mais la cible pourrait aussi bien être la concentration dans la biophase ou le site effecteur au cerveau.

L'évaluation clinique du Diprifusor TCI a montré que ce système prédisait à la baisse la concentration sanguine actuelle, avec un MDAPE d'environ 20-26\% et un MDPE de $16 \%$. Ces erreurs de fonctionnement reflètent la variabilité cinétique interindividuelle. Des prédictions à la baisse identiques ont aussi été notées avec les systèmes manuels de perfusion (PD moyenne 17-22\% ; APE moyenne 25-30\%). ${ }^{25}$ Avec tous les régimes de perfusion contrôlée par la cinétique, la prédictabilité sera influencée par la pertinence des données cinétiques introduites et réglées selon un scénario clinique donné.

Jusqu'à maintenant, peu de données ont été publiées sur la qualité de l'induction et de l'entretien avec le Diprifusor ou sur la comparaison avec d'autres systèmes ; ces données sont attendues avec impatience. Cependant, des comptes rendus non publiés suggèrent que le TCI pourrait améliorer la durée de l'induction et réduire la fréquence des réactions à l'incision ou à d'autres stimuli chirurgicaux pendant la phase d'entretien. Les effets hémodynamiques semblent comparables à ceux procurés par les régimes de perfusion manuelle utilisés pour l'administration du propofol. De nouvelles études aléatoires et en double aveugle sont nécessaires pour confirmer les données initiales.

\section{Références}

(Voir page R6) 